\title{
GENETIC DIFFERENTIATION OF DABBLING DUCKS (Anseriformes: Anas) POPULATIONS FROM PALAEARCTIC IN TIME AND SPACE
}

\author{
Algimantas Paulauskas*, Vaida Tubelyte*, Vykintas Baublys*, and Aniolas Sruoga ${ }^{*, \star \star}$ \\ * Vytautas Magnus University, Daukanto 28, Kaunas, LT-3000, LITHUANIA \\ ** Institute of Ecology, Vilnius University, Akademijos 2, Vilnius, LT-2600, LITHUANIA \\ E-mail: a.paulauskas@gmf.vdu.It
}

Communicated by İzaks Rašals

The genetic variation among populations of dabbling ducks (563 samples of A. acuta, A. clypeata, A. crecca, A. querquedula, A. falcata, A. penelope, A. platyrhynchos) in the Palaearctic region (Lithuania, Chukotka, Kamchatka, Lena, Ob and Kara rivers) was investigated between 1980 and 1998. Fifteen loci of blood serum proteins were surveyed for genetic variation using polyacrylamid gel electrophoresis, and eight polymorphic loci were found. The analysis of genetic variation at population and species levels shows that allele frequencies are temporarily variable. The general genetic diversity of dabbling ducks differed among geographically different populations: for Northern Pintail between $H_{0}=0.264$ from Ob river and $H_{0}=0.331$ from Kamchatka; for Eurasian Wigeon between $H_{0}=0.185$ from $\mathrm{Ob}$ and $H_{0}=0.263$ from Lena river. In Mallard populations mean heterozygosity ranged from $H_{0}=0.242$ (Vente 1998, Lithuania) to $H_{0}=0.366$ (Antanavas 1987, Lithuania). The data obtained from genetic distances revealed that Mallards of Lithuania form no discrete populations and vary temporarily and spatially.

Key words: palaearctic, genetic variability, Anas, blood plasma proteins.

\section{INTRODUCTION}

In recent years, a diverse array of molecular genetic tools has become available for high-resolution genetic studies of population-level processes in ecosystems. Genetic markers have been employed to characterise patterns of genetic variation within and among populations, and to examine the processes of dispersal and the patterns of mating that influence levels of genetic differentiation in ecosystems (Nevo et al., 1984, Parker et al., 1998). To achieve these aims in waterfowl species various techniques have been used: protein polymorphism (Kuznetsov et al., 1995, 1998; Rhodes et al., 1996; Sruoga et al., 1998; 2005), microsatellite polymorphism (McCracken et al., 2001; Williams et al., 2002; Slavenaite et al., 2004; Sruoga et al., 2005; Ahmadi et al., 2007), RAPD (Kulikova et al., 2003), mtDNA haplotypes (Scribner et al., 2001; Pearce et al., 2004; Kulikova et al., 2005), genetic maps (Huand et al., 2006), and MHC genes (Xia et al., 2004). These studies have contributed an evolutionary dimension to our understanding of contemporary ecological processes and the role of various organisms in ecosystems. Genetic variability is considered an essential prerequisite for adaptation to changing environmental conditions (Soulé, 1986).

It is important to understand the patterns of migration among wintering and breeding grounds, and survival and reproductively success of dabbling ducks (Doherty et al., 2002; Blums and Clark, 2004; Drever and Clark, 2007). Philopatry is characteristic of several bird species (Evrard 1990; Robertson 1999; Cooke et al., 2000; Iverson et al., 2004). Genetic information helps to understand the extent of philopatry in dabbling ducks and within migratory families and different species. On the basis of ringing recoveries (Scott and Rose 1996), dabbling ducks have been divided into different populations, but no discrete populations are identifiable.

Dabbling ducks are widespread worldwide. Species of the genus Anas display long-distance dispersal (Johnson and Sorenson, 1999) and it has been suggested that superior dispersal ability in birds results in different biogeographical patterns compared with those commonly observed for other organisms (Chesser and Zink, 1994). The wide distribution of dabbling ducks shows that dispersal-driven speciation has been common in this group of birds (Chesser and Zink, 1994; Ronquist, 1997). To fully interpret the biogeographical pattern of dabbling ducks, it is important to place species distributions in a phylogenetic context based on genetic research.

New genes appear in populations of dabbling ducks not only by paring between different sub-populations, but also due to hybrids. Williams and colleagues (2004) noted that 
Mottled ducks and Mallard populations exhibited hybridisation rates ranging from zero to $24 \%$ in different areas of Florida. Compared with other dabbling ducks, Mallards shows the biggest rate of hybridisation with other closely related species (McCracken et al., 2001; Kulikova et al., 2005).

The aim of this study was to examine and evaluate the temporal and spatial genetic variability of different populations of dabbling ducks Anas and to determine the level of fragmentation in Lithuanian Mallard species.

\section{MATERIALS AND METHODS}

Blood serum of 319 samples of Northern Pintail Anas acuta, Northern Shoveler A. clypeata, Common Teal A. crecca, Garganey A. querquedula, Falcated Duck A. falcata, Eurasian Wigeon A. penelope were collected between 1980 and 1998 in different localities of Siberia (Chukchia, Kamchatka in 1981 (KAM81), 1988 (KAM88), the Lena in 1989 (LENA89), Ob in 1982 (OB82), 1984 (OB84), 1986 (OB86) and Kara in 1985 (KARA85) rivers) and 244 samples of Mallards A. platyrhynchos from Lithuania (Antanavas in 1980-1989 (ANT80 to ANT89), Zuvintas in 1984 (ZUV84), Nemunas delta in 1998 (VEN98)) (Table 1). The geographical locations of the studied dabbling ducks are shown in Figure 1.

Blood sampling (about $5 \mathrm{ml}$ of blood) was made by wing vein puncture into test tubes with heparin. After shooting, blood was taken immediately from bird heart. Samples were centrifuged at room temperature for $15 \mathrm{~min}$ at $6,000 \mathrm{~g}$. The plasma was separated and stored in a fridge at $20{ }^{\circ} \mathrm{C}$ below zero until use.

In total fifteen loci of enzyme and plasma proteins were separated electrophoretically: lactate dehydrogenase (LDH, 1. 1. 1. 27, Ldh-1, 2), malate dehydrogenase (MDH, 1. 1. 1.

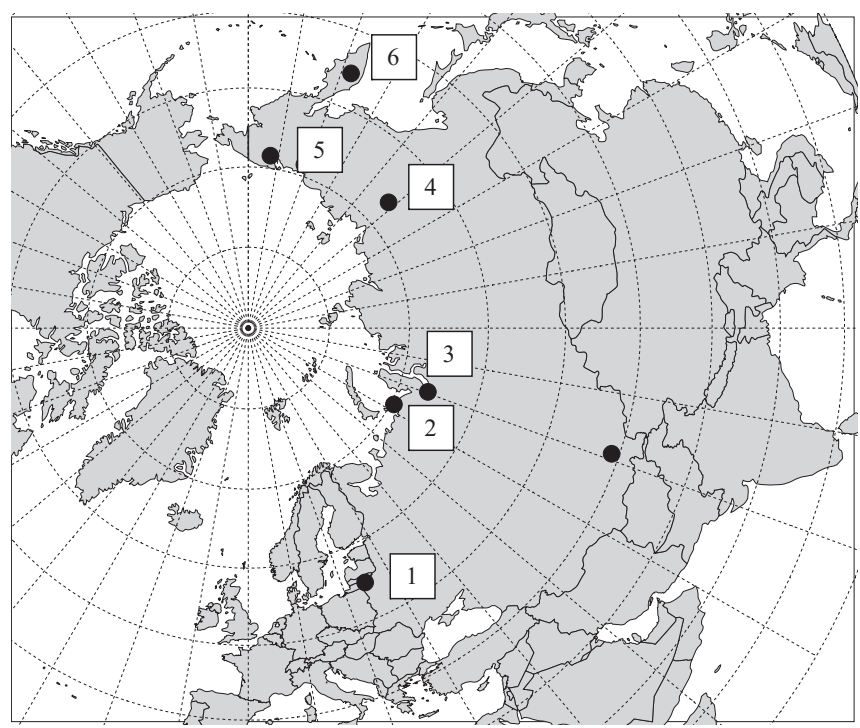

Fig. 1. Geographical location of the studied dabbling ducks: 1, Lithuania; 2, Kara river; 3, Ob delta; 4, Lena and Viluy river confluence; 5, Chukchia; 6, Kamchatka.
37, $M d h$ ), alkaline phosphatase (ALP, 3. 1. 3. 1, Alp), esterase (EST, 4. 2. 1. 1, Est-6, 7), ceruloplasmin (CEP, Cep-2), pre-albumin (PRA, Pra-1, 2), albumin (ALB, Alb), post-albumin (POA, Poa), pre-transferrin (PRT, Prt), transferrin (TRF, Trf), post-transferrin (POT, Pot), and macroglobulin (MCG, $\mathrm{Mcg}$ ). Isozymes were detected by non-denaturing vertical gel electrophoresis (PAGE). Samples were loaded into two-layer $(2.5 / 7.5 \%)$ polyacrylamide gel blocks. Protein electrophoresis were made in $10 \%$ Tris-glycine buffer (0.0495 M Tris, $0.383 \mathrm{M}$ glycine, $\mathrm{pH} \sim$ 8.3-8.5). Enzymes and plasma proteins were visualised using the staining system of Show and Prasad (1970) with few modifications as described earlier (Paulauskas and Sruoga, 1993, Sruoga et al., 1999). Allelic variants were resolved by direct side-by-side comparison of migrating allozymes on the same gels. Indistinct polymorphic loci were not included in further analysis.

Table 1

LOCATION, YEAR OF COLLECTION AND ACRONYM OF 11 GEOGRAPHIC SAMPLES OF 7 DIFFERENT Anas SPECIES AND THEIR POPULATIONS

\begin{tabular}{|c|c|c|c|c|c|}
\hline Species & Loc & ation & Acronym & $\begin{array}{c}\text { The year } \\
\text { of sam- } \\
\text { pling }\end{array}$ & $\mathrm{N}$ \\
\hline \multirow[t]{4}{*}{ A. acuta } & Ob River & $66^{\circ} \mathrm{N}, 65^{\circ} \mathrm{E}$ & OB84 & 1984 & 41 \\
\hline & Kara River & $69^{\circ} \mathrm{N}, 64^{\circ} \mathrm{E}$ & KAR85 & 1985 & 6 \\
\hline & Ob River & $66^{\circ} \mathrm{N}, 65^{\circ} \mathrm{E}$ & OB86 & 1986 & 16 \\
\hline & Kamchatka & $56^{\circ} \mathrm{N}, 161^{\circ} \mathrm{E}$ & KAM88 & 1988 & 15 \\
\hline \multirow[t]{3}{*}{ A. clypeata } & Kamchatka & $56^{\circ} \mathrm{N}, 162^{\circ} \mathrm{E}$ & KAM81 & 1981 & 5 \\
\hline & Ob River & $66^{\circ} \mathrm{N}, 65^{\circ} \mathrm{E}$ & OB84 & 1984 & 4 \\
\hline & Ob River & $66^{\circ} \mathrm{N}, 65^{\circ} \mathrm{E}$ & OB86 & 1986 & 8 \\
\hline A. creca & Ob River & $66^{\circ} \mathrm{N}, 65^{\circ} \mathrm{E}$ & OB86 & 1986 & 4 \\
\hline A. falcata & Kamchatka & $56^{\circ} \mathrm{N}, 161^{\circ} \mathrm{E}$ & KAM88 & 1988 & 27 \\
\hline \multirow[t]{3}{*}{ A. querqeudula } & Ob River & $66^{\circ} \mathrm{N}, 65^{\circ} \mathrm{E}$ & OB84 & 1984 & 22 \\
\hline & Ob River & $66^{\circ} \mathrm{N}, 65^{\circ} \mathrm{E}$ & OB86 & 1986 & 68 \\
\hline & Kamchatka & $56^{\circ} \mathrm{N}, 161^{\circ} \mathrm{E}$ & KAM88 & 1988 & 9 \\
\hline \multirow[t]{3}{*}{ A. penelope } & Ob River & $67^{\circ} \mathrm{N}, 66^{\circ} \mathrm{E}$ & OB82 & 1982 & 10 \\
\hline & Ob River & $66^{\circ} \mathrm{N}, 65^{\circ} \mathrm{E}$ & OB84 & 1984 & 34 \\
\hline & Lena river & $64^{\circ} \mathrm{N}, 125^{\circ} \mathrm{E}$ & LEN89 & 1989 & 50 \\
\hline \multirow[t]{12}{*}{ A. plathyrhynchos } & Lithuania & $55^{\circ} \mathrm{N}, 23^{\circ} \mathrm{E}$ & ANT80 & 1980 & 36 \\
\hline & Lithuania & $55^{\circ} \mathrm{N}, 23^{\circ} \mathrm{E}$ & ANT81 & 1981 & 12 \\
\hline & Lithuania & $55^{\circ} \mathrm{N}, 23^{\circ} \mathrm{E}$ & ANT82 & 1982 & 11 \\
\hline & Lithuania & $55^{\circ} \mathrm{N}, 23^{\circ} \mathrm{E}$ & ANT83 & 1983 & 9 \\
\hline & Lithuania & $55^{\circ} \mathrm{N}, 23^{\circ} \mathrm{E}$ & ANT84 & 1984 & 10 \\
\hline & Lithuania & $55^{\circ} \mathrm{N}, 23^{\circ} \mathrm{E}$ & ANT85 & 1985 & 18 \\
\hline & Lithuania & $55^{\circ} \mathrm{N}, 23^{\circ} \mathrm{E}$ & ANT86 & 1986 & 37 \\
\hline & Lithuania & $55^{\circ} \mathrm{N}, 23^{\circ} \mathrm{E}$ & ANT87 & 1987 & 19 \\
\hline & Lithuania & $55^{\circ} \mathrm{N}, 23^{\circ} \mathrm{E}$ & ANT89 & 1989 & 8 \\
\hline & Lithuania & $\begin{array}{l}54^{\mathrm{o}} 30^{\prime} \mathrm{N}, \\
23^{\circ} 40^{\prime} \mathrm{E}\end{array}$ & ZUV84 & 1984 & 39 \\
\hline & Lithuania & $\begin{array}{l}55^{\circ} 20^{\prime} \mathrm{N}, \\
21^{\mathrm{o}} 20^{\prime} \mathrm{E}\end{array}$ & PAN86 & 1986 & 29 \\
\hline & Lithuania & $\begin{array}{l}55^{\circ} 40^{\prime} \mathrm{N}, \\
24^{\mathrm{O}} 30^{\prime} \mathrm{E}\end{array}$ & VEN98 & 1998 & 16 \\
\hline
\end{tabular}

$\overline{\mathrm{N} \text {, number of individuals }}$ 
Temporal and spatial population differences of dabbling ducks have been described in time and space by standard measures using BIOSYS-2 (Swofford et al., 1997). Genetic variability parameters-frequency of allele, of genotype, significance test using exact probabilities for deviation of genotype frequencies from Hardy-Weinberg expectations, the percentage of polymorphic loci (P) (a locus was considered to be polymorphic if the frequency of the most common allele did not exceed 0.95 ), the mean number of alleles per locus (A) and average heterozygosities $\left(\mathrm{H}_{\mathrm{O}}\right.$ - observed, $\mathrm{H}_{\mathrm{e}}$ - expected), were calculated for each geographical sample. Relative genetic distance and similarity between populations and species were quantified according to Roger's modified distance (Wright, 1978).

\section{RESULTS}

Of the 15 loci analyzed, seven loci $(L d h-1,2, M d h, A l p$, Cep-2, Est-6, 7) were monomorphic in all species investigated. Eight loci - Pra-1, 2, Alb, Poa, Prt, Trf, Pot and $M c g$, were polymorphic for each dabbling ducks species. The mean value of polymorphic loci in blood plasma proteins for all dabbling ducks examined was similar $-53.3 \%$.

Tests of significance using exact probabilities for deviation of genotype frequencies from Hardy-Weinberg expectations showed significant gene frequency differences among popu- lations. Allele $A l b^{C}$ was found only in one population of Eurasian Wigeon (from Lena, 1989). It must be noted, that the rear $\operatorname{Trf}^{E}$ allele of the polyallelic system of transferrins was detected only in two Siberian populations of dabbling ducks (Garganey from Ob, 1986, and Kamchatka, 1988) and even in six populations of Mallard from Lithuania (from Antanavas 1980, 1983, 1985, 1986, 1987 and from Zuvintas 1984). The alleles $\operatorname{Tr}^{E}$ and $\operatorname{Tr} f^{D}$ were not found in all Northern Shoveler and Falcated duck populations (Kama 1981, 1988, and Ob 1984, 1986, Siberia) and one Mallard population (Nemunas delta 1998, Lithuania). The gene frequencies at polymorphic loci in the population of studied dabbling ducks from Siberia and Lithuania are shown in Tables 2 and 3 .

The analysis of genetic variation among species showed that genotype frequency was divergent for different population of dabbling ducks in all species examined. The loci Alb-1, Mcg-1 and Trf- 1 had the highest frequency of heterozygous genotypes. Individual heterozygous in these loci individuals in Mallard population constituted from 61 to $75 \%$. Heterozygous $A l b-1$ locus individuals in the Eurasian Wigeon populations constituted $69 \%$, in Falcated ducks $81 \%$.

Genetic variability estimated by mean number of alleles per locus, percentage of loci polymorphic, mean observed and expected heterozygosity, in different Anas populations was

Table 2

ALLELE FREQUENCIES OF POLYMORPHIC LOCI OF A. acuta, A. clypeata, A. crecca, A. querquedula, A. falcate, A. penelope FROM DIFFERENT POPULATIONS

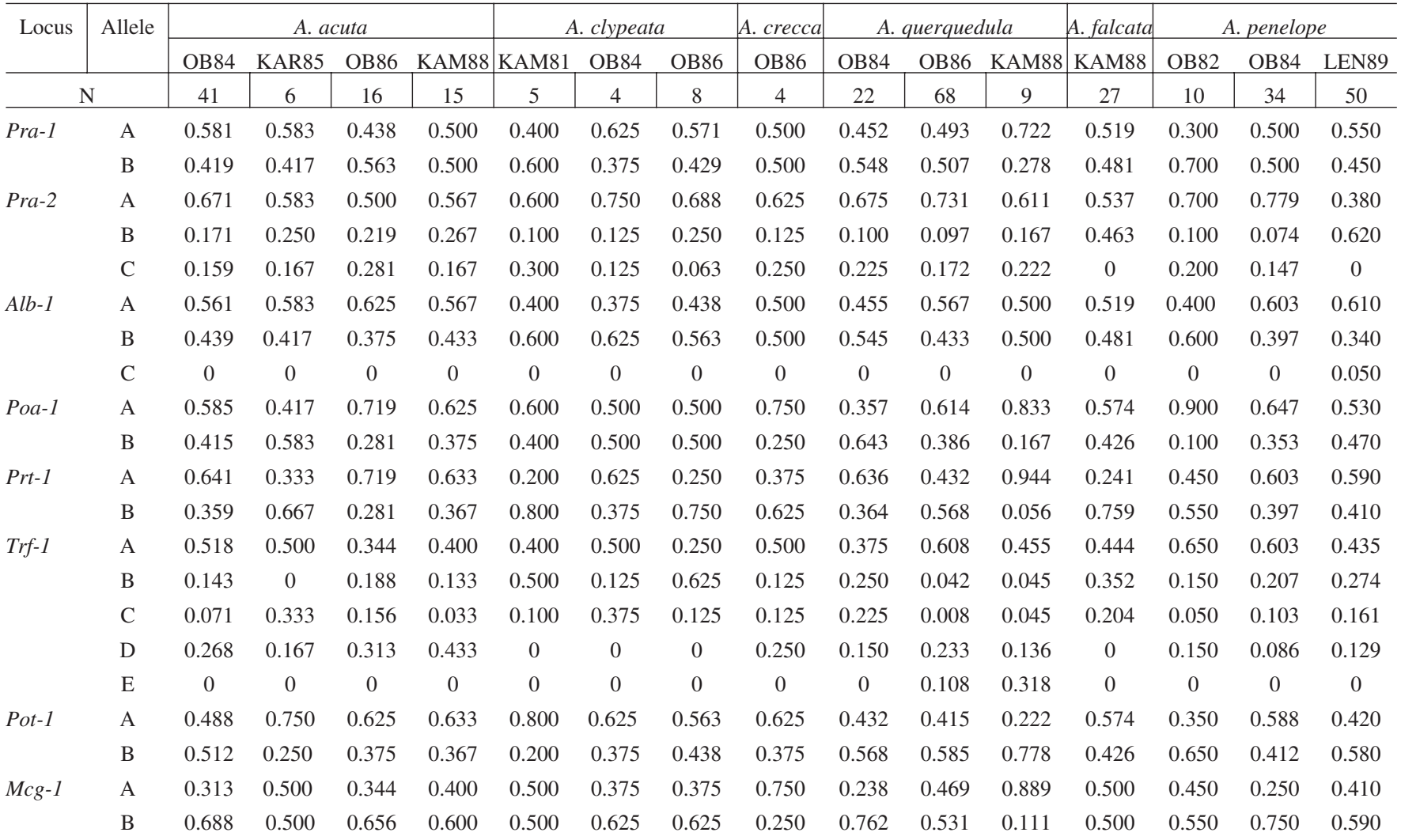

N, number of individuals. For acronyms see Fig.1 and Table 1. 
ALLELE FREQUENCIES OF POLYMORPHIC LOCI OF Anas platyrhynchos FROM DIFFERENT POPULATIONS

\begin{tabular}{|c|c|c|c|c|c|c|c|c|c|c|c|c|c|}
\hline \multirow[t]{2}{*}{ Locus } & \multirow[t]{2}{*}{ Allele } & \multicolumn{12}{|c|}{ A. platyrhynchos } \\
\hline & & ANT80 & ANT81 & ANT82 & ANT83 & ANT84 & ANT85 & ANT86 & ANT87 & ANT89 & ZUV84 & PAN86 & VEN98 \\
\hline $\mathrm{N}$ & & 36 & 12 & 11 & 9 & 10 & 18 & 37 & 19 & 8 & 39 & 29 & 16 \\
\hline \multirow[t]{2}{*}{ Pra-1 } & A & 0.475 & 0.792 & 0.455 & 0.778 & 0.600 & 0.750 & 0.405 & 0.553 & 0.750 & 0.707 & 0.621 & 0.875 \\
\hline & $\mathrm{B}$ & 0.528 & 0.208 & 0.545 & 0.222 & 0.400 & 0.250 & 0.595 & 0.447 & 0.250 & 0.293 & 0.379 & 0.125 \\
\hline \multirow[t]{3}{*}{ Pra-2 } & A & 0.792 & 0.500 & 1.000 & 0.833 & 0.700 & 0.800 & 0.730 & 0.500 & 0.500 & 0.923 & 0.643 & 0.813 \\
\hline & $\mathrm{B}$ & 0.194 & 0.500 & 0 & 0.111 & 0.250 & 0.050 & 0.162 & 0.237 & 0.313 & 0.064 & 0.071 & 0.125 \\
\hline & $\mathrm{C}$ & 0.014 & 0 & 0 & 0.056 & 0.050 & 0.150 & 0.108 & 0.263 & 0.188 & 0.013 & 0.286 & 0.063 \\
\hline \multirow[t]{3}{*}{$A l b-1$} & A & 0.556 & 0.500 & 0.545 & 0.444 & 0.300 & 0.611 & 0.486 & 0.447 & 0.063 & 0.066 & 0.431 & 0.250 \\
\hline & $\mathrm{B}$ & 0.444 & 0.375 & 0.455 & 0.556 & 0.700 & 0.389 & 0.514 & 0.553 & 0.938 & 0.934 & 0.569 & 0.750 \\
\hline & $\mathrm{C}$ & 0 & 0.125 & 0 & 0 & 0 & 0 & 0 & 0 & 0 & 0 & 0 & 0 \\
\hline \multirow[t]{2}{*}{ Poa-1 } & A & 0.764 & 0.542 & 0.591 & 0.556 & 0.750 & 0.611 & 0.514 & 0.395 & 0.688 & 0.487 & 0.534 & 0.625 \\
\hline & B & 0.236 & 0.458 & 0.409 & 0.444 & 0.250 & 0.389 & 0.486 & 0.605 & 0.313 & 0.513 & 0.466 & 0.375 \\
\hline \multirow[t]{2}{*}{ Prt-1 } & A & 0.556 & 0.542 & 0.455 & 0.444 & 0.450 & 0.722 & 0.473 & 0.632 & 0.438 & 0.439 & 0.690 & 0.625 \\
\hline & B & 0.444 & 0.458 & 0.545 & 0.556 & 0.550 & 0.278 & 0.527 & 0.368 & 0.563 & 0.561 & 0.310 & 0.375 \\
\hline \multirow[t]{5}{*}{$\operatorname{Trf}-1$} & A & 0.556 & 0.273 & 0.545 & 0.056 & 0.357 & 0.188 & 0.519 & 0.184 & 0.125 & 0.167 & 0.345 & 0.625 \\
\hline & B & 0.019 & 0.318 & 0.182 & 0.444 & 0.214 & 0.313 & 0.037 & 0.263 & 0.188 & 0.303 & 0.155 & 0.250 \\
\hline & $\mathrm{C}$ & 0.037 & 0.091 & 0.182 & 0.111 & 0.214 & 0.188 & 0.204 & 0.053 & 0.188 & 0.030 & 0.103 & 0.125 \\
\hline & $\mathrm{D}$ & 0.278 & 0.318 & 0.091 & 0.278 & 0.214 & 0.250 & 0.167 & 0.395 & 0.500 & 0.121 & 0.397 & 0 \\
\hline & $\mathrm{E}$ & 0.111 & 0 & 0 & 0.111 & 0 & 0.063 & 0.074 & 0.105 & 0 & 0.379 & 0 & 0 \\
\hline \multirow[t]{2}{*}{ Pot-1 } & A & 0.529 & 0.375 & 0.682 & 0.333 & 0.550 & 0.375 & 0.568 & 0.526 & 0.750 & 0.438 & 0.379 & 0.375 \\
\hline & B & 0.471 & 0.625 & 0.318 & 0.667 & 0.450 & 0.625 & 0.432 & 0.474 & 0.250 & 0.563 & 0.621 & 0.625 \\
\hline \multirow[t]{2}{*}{ Mcg-1 } & A & 0.431 & 0.333 & 0.682 & 0.889 & 0.400 & 0.563 & 0.459 & 0.500 & 0.750 & 0.618 & 0.552 & 0.375 \\
\hline & B & 0.569 & 0.667 & 0.318 & 0.111 & 0.600 & 0.438 & 0.541 & 0.500 & 0.250 & 0.382 & 0.448 & 0.625 \\
\hline
\end{tabular}

N, number of individuals. For acronyms see Fig.1 and Table 1.

calculated from the allele frequencies of 15 characterised gene loci (Table 4). The mean of values positively correlates with the level of genetic variability. The genetic diversity for dabbling ducks examined fluctuated among geographically different populations: for Northern Pintail fluctuated between $\mathrm{H}_{\mathrm{o}}=0.264$ from $\mathrm{Ob}$ river and $\mathrm{H}_{\mathrm{o}}=$ 0.331 from Kamchatka; for Eurasian Wigeon - between
$\mathrm{H}_{\mathrm{o}}=0.185$ from $\mathrm{Ob}$ and $\mathrm{H}_{\mathrm{o}}=0.263$ from Lena river. In Mallard populations mean heterozygosity ranged from $\mathrm{H}_{\mathrm{o}}=$ 0.242 (Vente 1998, Lithuania) to $\mathrm{H}_{\mathrm{o}}=0.366$ (Antanavas 1987, Lithuania). Author's analysis was conducted using a modified Rogers genetic distance (Wright, 1978) to show the genetic relationship among the Mallard populations studied in Lithuania (Figure 2).

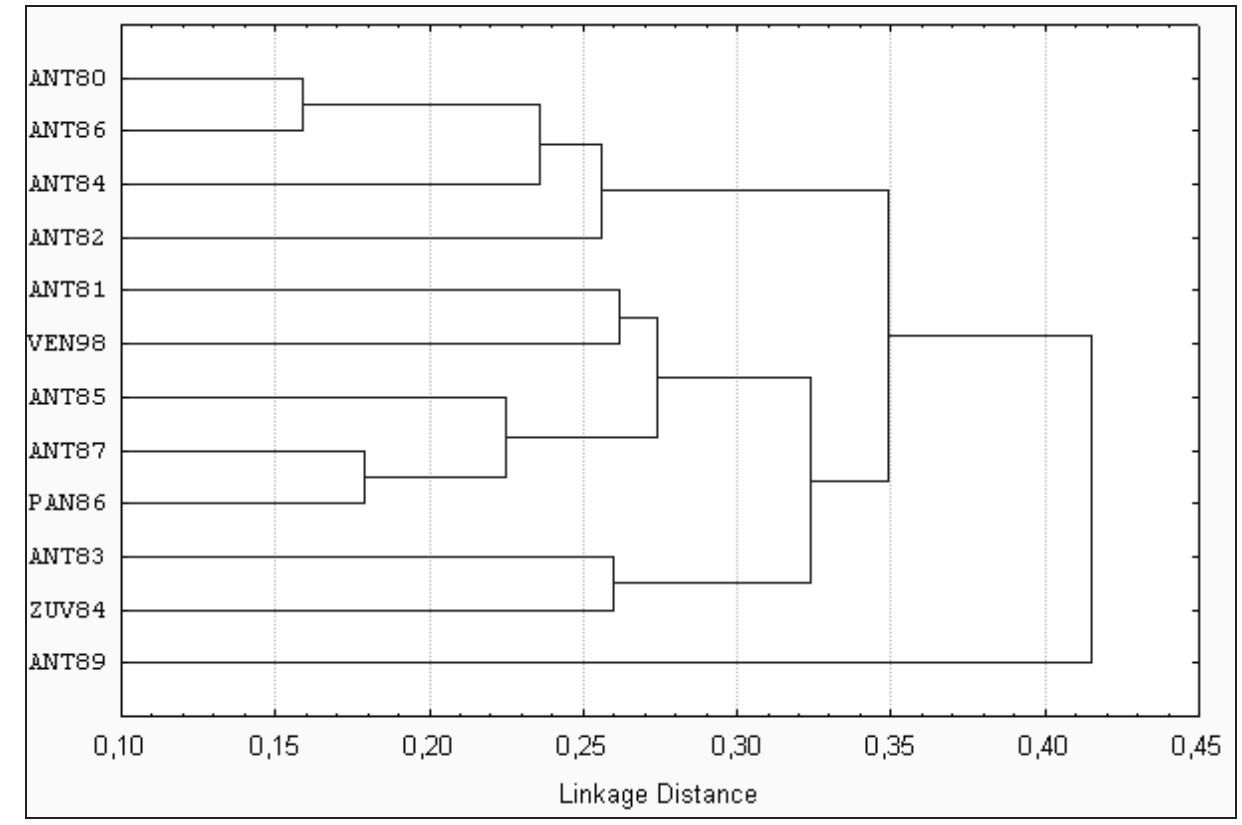

Fig. 2. Distance-based cluster analysis of Lithuanian Mallard populations from different localities. Modified Roger's distance were used. For acronyms see Table 1. 
GENETIC VARIABILITY OF 15 LOCI IN DIFFERENT Anas POPULATIONS (STANDARD ERRORS IN PARENTHESES)

\begin{tabular}{|c|c|c|c|c|c|}
\hline \multirow[t]{2}{*}{ Species } & \multirow[t]{2}{*}{$\mathrm{n}$} & \multirow[t]{2}{*}{ A } & \multirow[t]{2}{*}{$\mathrm{P} *$} & \multicolumn{2}{|c|}{ Mean heterozygosity } \\
\hline & & & & $\mathrm{H}_{0}$ & $\mathrm{H}_{e}^{* *}$ \\
\hline \multicolumn{6}{|l|}{ A acuta } \\
\hline OB84 & $40.0(0.9)$ & $1.7(0.2)$ & 53.3 & $0.264(0.087)$ & $0.269(0.068)$ \\
\hline KAR85 & $6.0(0.0)$ & $1.7(0.2)$ & 53.3 & $0.278(0.097)$ & $0.288(0.073)$ \\
\hline OB86 & $16.0(0.0)$ & $1.7(0.2)$ & 53.3 & $0.304(0.100)$ & $0.278(0.073)$ \\
\hline KAM88 & $14.5(0.5)$ & $1.7(0.2)$ & 53.3 & $0.331(0.096)$ & $0.283(0.072)$ \\
\hline \multicolumn{6}{|l|}{ A.clypeata } \\
\hline KAM81 & $5.0(0.0)$ & $1.7(0.2)$ & 53.3 & $0.213(0.084)$ & $0.274(0.071)$ \\
\hline OB84 & $4.0(0.0)$ & $1.7(0.2)$ & 53.3 & $0.317(0.093)$ & $0.293(0.074)$ \\
\hline OB86 & $7.9(0.1)$ & $1.7(0.2)$ & 53.3 & $0.277(0.082)$ & $0.271(0.068)$ \\
\hline \multicolumn{6}{|l|}{ A. creca } \\
\hline \multicolumn{6}{|l|}{ A.falcata } \\
\hline \multicolumn{6}{|l|}{ A. querqeudula } \\
\hline $\begin{array}{l}\text { OB84 } \\
\text { OB86 }\end{array}$ & $\begin{array}{l}21.5(0.2) \\
66.7(0.6)\end{array}$ & $\begin{array}{l}1.7(0.2) \\
1.8(0.3)\end{array}$ & $\begin{array}{l}53.3 \\
53.3\end{array}$ & $\begin{array}{l}0.271(0.087) \\
0.213(0.069)\end{array}$ & $\begin{array}{l}0.271(0.070) \\
0.264(0.066)\end{array}$ \\
\hline KAM88 & $9.9(0.9)$ & $1.8(0.3)$ & 53.3 & $0.222(0.098)$ & $0.213(0.064)$ \\
\hline \multicolumn{6}{|l|}{ A. penelope } \\
\hline OB82 & $9.7(0.3)$ & $1.7(0.2)$ & 53.3 & $0.220(0.078)$ & $0.247(0.065)$ \\
\hline OB84 & $33.7(0.3)$ & $1.7(0.2)$ & 53.3 & $0.185(0.066)$ & $0.251(0.064)$ \\
\hline LEN89 & $48.7(1.3)$ & $1.7(0.2)$ & 53.3 & $0.263(0.082)$ & $0.278(0.071)$ \\
\hline \multicolumn{6}{|l|}{ A. plathyrhynchos } \\
\hline ANT80 & $35.4(0.6)$ & $1.8(0.3)$ & 53.3 & $0.255(0.076)$ & $0.254(0.065)$ \\
\hline ANT81 & $11.3(0.6)$ & $1.7(0.2)$ & 53.3 & $0.255(0.086)$ & $0.287(0.075)$ \\
\hline ANT82 & $10.3(0.7)$ & $1.6(0.2)$ & 53.3 & $0.224(0.076)$ & $0.242(0.070)$ \\
\hline ANT83 & $9.0(0.0)$ & $1.9(0.3)$ & 53.3 & $0.259(0.099)$ & $0.271(0.072)$ \\
\hline ANT84 & $9.8(0.2)$ & $1.7(0.2)$ & 53.3 & $0.300(0.083)$ & $0.277(0.072)$ \\
\hline ANT85 & $17.1(0.1)$ & $1.8(0.3)$ & 53.3 & $0.266(0.085)$ & $0.273(0.074)$ \\
\hline ANT86 & $36.3(0.7)$ & $1.8(0.3)$ & 53.3 & $0.297(0.088)$ & $0.274(0.070)$ \\
\hline ANT87 & $17.2(0.6)$ & $1.8(0.3)$ & 53.3 & $0.366(0.107)$ & $0.293(0.075)$ \\
\hline ANT89 & $8.0(0.0)$ & $1.7(0.2)$ & 53.3 & $0.275(0.095)$ & $0.245(0.070)$ \\
\hline ZUV84 & $36.9(0.8)$ & $1.8(0.3)$ & 53.3 & $0.290(0.094)$ & $0.227(0.068)$ \\
\hline PAN86 & $28.5(0.5)$ & $1.7(0.2)$ & 53.3 & $0.303(0.098)$ & $0.274(0.070)$ \\
\hline VEN98 & $16.0(0.0)$ & $1.7(0.2)$ & 53.3 & $0.242(0.065)$ & $0.254(0.062)$ \\
\hline
\end{tabular}

* A locus is considered polymorphic if the frequency of the most common allele does not exceed 0.95 ;

** Unbiased estimate (see Nei, 1978)

\section{DISCUSSION}

There is a great range in geographical regions and habitats used by different biogeographical populations of the ducks. The concept of "geographical population" was elaborated for migratory populations of birds by Isakov (1967) and modified by Atkinson-Wiles et al. (1982) as a "biogeographical population", which comprises a discrete population unit with a specific flyway, linking the breeding, moulting and wintering grounds. Such a distributing range of populations spatially and temporally may be the outcome of alteration in wetland ecosystems.

Very different environmental conditions are characteristic for the biogeographical populations of dabbling ducks in the Palaearctic. The distribution range of the Northwest
Europe population generally coincides with a maritime climate on vast plains usually located not far from the coast of Atlantic and Arctic Oceans, in European tundra, boreal and temperate zones. The Eastern-Central Europe/Mediterranean region population is mainly located within a continental climate in the temperate and Mediterranean zones of Europe and in the sub-tropical zone of North-West Africa. The distribution range of the SE Europe/SW Asia/East Africa population generally coincides with the steppe zone of Europe/SW Asia and savannah region in East Africa. Thus, the genetic differentiation between the biographical populations can be caused by the ecological and geographical isolation. Natural selection can be an important factor, as different populations of dabbling ducks breed, migrate and winter in very different habitats. 
Similar observations have been reported for other waterbird species population. For example, the NW Europe, East Europe/Mediterranean and West Siberian/Caspian/East Africa populations have been delineated for common European duck species (Mallard, Common Teal, Northern Pintail, Eurasian Wigeon and Garganey) by Shevareva (1970) based on nearly 11,000 ring recoveries. Later the population range limits were slightly modified by Atkinson-Wiles et al. (1982) and recently by Scott and Rose (1996).

Our data shows that the dabbling duck species examined form no discrete populations, as dabbling ducks show low philopatric compared with other waterbirds (Robertson and Gregory, 1999), and due to large local migration in the breeding grounds (Doherty et al., 2002). The genetic variability of dabbling ducks is also raised by yearly change of breeding pairs (Lossito and Baltassarre, 1996).

The data obtained for Lithuanian Mallards confirmed genetic differences among the populations studied (Fig. 2). Cluster analysis showed that individuals sampled from the same place (Antanavas) for nine years did not form a discrete population, and furthermore mixed with Mallards from more distant Lithuania sites (Panevezys, Nemunas delta, Zuvintas). The gene frequency data confirms differences among Antanavas breeding populations studied annually from 1980 to 1989 : allele $A l b-I^{C}$ was detected only in the ANT81 population, $P r a-2^{B}$ not found only in ANT82, Pra- $2^{C}$ - not founded in ANT81 and ANT82 populations, $\operatorname{Trf}-1^{E}$ - not founded in ANT81, ANT82, ANT84, and ANT89 populations (Table 3). The results strongly support the hypothesis that dabbling ducks are not philopatric, exhibit large local migration, and show low fidelity to breeding grounds.

All Siberia populations of species examined also differed considerably in a temporal and spatial context (Table 4). Best it could be revealed for Northern Pintail species: OB84 population was more similar to the Kamchatka population (KAM88) than to populations from the Ob river in 1986 and Kara river in 1985 . These results are not very surprising. Four migratory ways cross the $\mathrm{Ob}$ and Kara rivers breeding grounds (Scott and Rose, 1996) which can explain the large genetic variability. Regarding the Kamchatka population it appears that the OB84 population was most likely a Middle Asia flyway migrant, rather than European/African, and inhabited Kamchatka in wintering grounds. The genetic data for other Siberian dabbling ducks shows no discrete populations. All three investigated populations of Garganey were genetically different; two Eurasian Wigeon groups from the $\mathrm{Ob}$ River formed different populations, but their genetic structure was similar to the Lena river group. Only genetic data of the Northern Shoveler corresponds to ornithological data (Scott and Rose, 1996): Ob River and Kamchatka populations migrate by different flyways; the group from $\mathrm{Ob}$ River in 1984 and 1986 had similar genetic structure and formed one population, while the group from Kamchatka differed genetically. Geographic and adaptive variation in different populations of waterbirds is closely associated with the environmental conditions in the different regions of Palaearctic.

\section{REFERENCES}

Ahmadi, A.K., Rahimi, G., Vafaei, A., Sayyazadeh, H. (2007). Microsatellite Analysis of Genetic Diversity in Pekin (Anas platyrhynchos) and Muscovy (Cairina moschata) Duck Populations. Int. J. Poult. Sci., 6(5), 378-382.

Atkinson-Wiles, G., Scott, D., Prater, A. (1982). Criteria for selecting wetlands of international importance. Proceedings of the International Conference on Wetlands of International Importance, Particularly as Waterfowl Habitats. Ricerche di Biologia della Selvaggina, 8(1), 1017-1042.

Blums, P., Clark, R.G. (2004). Correlates of lifetime reproductive success in three species of European ducks. Oecologia, 140, 61-67.

Chesser, R.T., Zink, R.M. (1994). Modes of Speciation in Birds: A Test of Lynch's Method. Evolution, 48(2), 490-497.

Cooke, F., Robertson, G.J., Smith, C.M., Goudie, R.I., Boyd, W.S. (2000). Survival, emigration and winter population structure of harlequin ducks. Condor, 102, 137-144.

Doherty, P.F., Nichols, J.D., Tautin, J., Voelzer, J.F., Smith, G.W., Benning, D.S., Bentley, V.R., Bidwell, J.K., Bollinger, K.S., Brazda, A.R., Buelna, E.K., Goldsberry, J.R., King, R.J., Roetker, F.H., Solberg, J.W., Thorpe, P.P., Wortham, J.S. (2002). Sources of variation in breeding-ground fidelity of mallards (Anas platyrhynchos). Behav. Ecol., 13(4), 543-550.

Drever, M.C., Clark, R.G. (2007). Spring temperature, clutch initiation date and duck nest success: a test of the mismatch hypothesis. J. Anim. Ecol., 76, $139-148$.

Evrard, J.O. (1990). Male philopatry in Mallards. Condor, 92, 248-251.

Huang, Y., Zhao, Y., Haley, C.S., Hu, S., Hao, J., Wu, C., Li, N. (2006). A genetic and cytogenetic map for the duck (Anas platyrhynchos). Genetics, 173, 287-296.

Isakov, Y. (1967). MAR project and conservation of waterfowl breeding in the USSR. In: Proceedings of the 2nd European Meeting on Wildfowl Conservation, Noordwijk aan Zee, the Netherlands, 9-14 May 1966 (pp. 125-138). Salverda, Z. (ed.). Amsterdam Ministry of Cultural Affairs, Recreation and Social Welfare.

Iverson, S.A., Esler, D., Rizzolo, D.J. (2004). Winter philopatry of harlequin ducks in Prince William Sound, Alaska. Condor, 106, 711-715.

Johnson, K.J., Sorenson, M.D. (1999). Phylogeny and biogeography of the dabbling ducks (Genus: Anas): A comparison of molecular and morphological evidence. Auk, 116, 792-805.

Kulikova, I.V., Chelomina, G.N., Zhuravlev, Y.N. (2003). Low genetic differentiation of and close evolutionary relationships between Anas platyrhynchos and Anas poecilorhyncha: RAPD-PCR Evidence. Russ. J. Genet., 39(10), 1143-1151.

Kulikova, I.V., Drovetski, S.V., Gibson, D.D., Harrigan, R.J., Rohwer, S., Sorenson, M.D., Winker, K., Zhuravlev, Y.N., McCracken, K.G. (2005). Phylogeography of the Mallard (Anas platyrhynchos): Hybridization, dispersal, and lineage sorting contribute to complex geographic structure. Auk, 122(3), 949-965.

Kuznetsov, B. (1995). Polymorphism of blood plasma esterases in geese of the Anser genus (Aves: Anseriformes). Biochem. Genet., 33, 183-187.

Kuznetsov, B.S., Baranyuk, V.V., Takekawa, J.Y. (1998). Genetic differentiation between wintering populations of lesser snow geese nesting on Wrangel island. Auk, 115(4), 1053-1057.

Losito, M.P., Baldassarre, G.A. (1996). Pair-bond Separation in Mallards. Auk, 113, 692-695.

McCracken, K.G., Johnson, W.P., Sheldon, F.H. (2001). Molecular population genetics, phylogeography, and conservation biology of the mottled duck (Anas fulvigula). Conserv. Genet., 2(2), 87-102.

Nevo, E., Beiles, A., Ben-Shlomi, R. (1984). The evolutionary significance of genetic diversity: Ecological, demographic, and life history correlates. In: Evolutionary dynamics of genetic diversity (pp. 13-213). Mani, G.S. (ed.). Mount Carmel Haifa. 
Parker, P.G., Snow, A.A., Schug, M.D., Booton, G.C., Fuerst, P.A. (1998). What molecules can tell us about populations: choosing and using a molecular marker. Ecology, 79(2), 361-382.

Paulauskas, A., Sruoga, A. (1993). The genetic structure of the Mallard (Anas platyrhynchos L.) population of Lake Zuvintas. In: The Zuvintas Reserve (pp. 437-445). V. Kontrimavicus (ed.). Vilnius.

Pearce, J.M., Talbot, S.L., Pierson, B.J., Petersen, M.R., Scribner, K.T., Dickson, D.L., Mosbech, A. (2004). Lack of spatial genetic structure among nesting and wintering king eiders. Condor, 106(2), 229-240.

Rhodes, O.E., Smith, L.M., Smith, M.H. (1996). Relationships between genetic variation and body size in wintering mallards. Auk, 113(2), 339-345.

Robertson, G.J. (1999). Winter philopatry in migratory waterfowl. Auk, 116(1), 20-34.

Scott, D., Rose, P. (1996). Atlas of Anatidae populations in Africa and Western Eurasia. Wetlands International Publication, 41, 1-336.

Scribner, K.T., Petersen, M.R., Fields, R.L., Talbot, S.L., Pearce, J.M., Chesser, R.K. (2001). Sex-biased gene flow in spectacled eiders (Anatidae): Inferences from molecular markers with contrasting modes of inheritance. Evolution, 55(10), 2105-2115.

Shevareva, T. (1970). Geographical distribution of the main dabbling duck populations in the USSR and the main directions of their migrations. In: Proceedings of the International Meeting on Conservation of Wildfowl Resources, Leningrad, 25-30 September 1968 (pp. 46-55). Isakov, Y. (ed.). Moscow.

Show, C.R., Prasad, R. (1970). Biochem. Genet., 4, 297-320.

Slavėnaitè, S., Butkauskas, D., Sruoga, A., Mozalienè, E. (2004). Comparative investigations of Mallard duck (Anas platyrhynchos) genomic DNA using chicken and duck specific microsatellite primers. Veterinarija ir Zootechnika, 26 (48), 89-92.

Soulé, M. (1986). Conservation biology: The science of scarcity and diversity. Sunderland, Massachussets.

Sruoga, A., Paulauskas, A., Mozalienè, E. (1999). Genetic variability of blood proteins in waterfowl from the order Anseriformes. Acta Zool. Lit., 9(4), 1-86.

Sruoga, A., Švažas, S., Butkauskas, D., Paulauskas, A., Mozalienè, E., Slavènaitè, S. (2005). Long-term genetic investigations — background for research on wildfowl populations in the changing environmental conditions. Acta Zool. Lit., 15(2), 169-172.

Sruoga, A., Vilkaitė, R., Paulauskas, A., Miceikienė, I., Janušauskas, K. (1998). Random amplified polymorphic DNA of individuals of the same species of order Anseriformes. Anim. Genet., 29 (Suppl. 1), 20.

Swofford, D.L., Selander, R.B., Black, C.W. (1997). BIOSYS-2: A computer program for analysis of allelic variation in population genetic and biochemical systematic. University of Illinois. Colorado State University.

Williams, C.L., Brust, R.C., Fendley, T.T., Tillerand, G.R., Rhodes O.E. (2004). A comparison of hybridization between mottled ducks and mallards in Florida and South Carolina using microsatellite DNA analysis. Conserv. Genet., 6, 445-453.

Williams, C.L., Brust, R.C., Rhodes, O.E. (2002). Microsatellite polymorphism and genetic structure of Florida Mottled duck populations. Condor, 104, 424-431.

Wright, S. (1978). Evolution and the Genetics of Populations IV: Variability within and among Natural Populations. Chicago: University of Chicago Press. 590 pp.

Xia, Y., Bjørnstad, O.N., Grenfell, B.T. (2004). Measles metapopulation dynamics: A gravity model for pre-vaccination epidemiological coupling and dynamics. Amer. Nat., 164, 267-281

Received 10 October 2007

PELDPĪḶU (Anseriformes: Anas) PALEARKTIKAS POPULĀCIJU ĢENĒTISKĀ DIFERENCIĀCIJA LAIKĀ UN TELPĀ

Pētìta ğenētiskā diferenciācija 15 asins sēruma proteīnu lokusos starp Palearktikas peldpīlu (A. acuta, A. clypeata, A. crecca, A. querquedula, A. falcata, A. penelope, A. platyrhynchos) ǵeogrāfiski attālinātām Lietuvas un Sibīrijas populācijām. Noteikti pētīto lokusu alẹlı izmaiņu trendi laikā un telpā. 